\title{
Pengembangan Perangkat Pembelajaran Fisika Strategi Konflik Kognitif berbasis Eksperimen untuk Mereduksi Miskonsepsi Peserta Didik SMA Konsep Fluida Statis
}

\author{
Sri Rahmadani Pulu ${ }^{1)}$, Widia $^{2), *}$ \\ ${ }^{1)}$ FITK, IAIN Ambon \\ ${ }^{2)}$ STKIP Harapan Bima \\ *widia.fisika09@gmail.com
}

Abstrak: Penelitian ini dilakukan untuk mengembangkan perangkat pembelajaran fisika strategi konflik kognitif berbasis eksperimen yang memenuhi kriteria: valid, praktis, dan efektif agar layak digunakan untuk mereduksi miskonsepsi peserta didik SMA pada materi fluida statis. Desain penelitian menggunakan four-D model yang cobakan pada tiga kelas X MIA dengan peserta didik sebanyak 90 orang di SMA Negeri 08 Maluku Tengah Tahun Ajaran 2020/2021. Penelitian menggunakan one group pretest-posttest design. Data yang dikumpulkan berupa data validasi perangkat pembelajaran, data kepraktisan perangkat pembelajaran, dan data keefektifan perangkat pembelajaran. Analisis data yang digunakan: 1) Analisis deskriptif kualitatif meliputi: Ketuntasan indikator, hasil belajar, penurunan miskonsepsi. 2) Analisis CRI meliputi: Intensitas miskonsepsi dan penurunan potensi miskonsepsi. Maka didapatkan data hasil penelitian sebagai berikut: 1) Validitas perangkat pembelajaran yang dikembangkan dengan kategori valid; 2) Kepraktisan perangkat pembelajaran ditinjau dari keterlaksanaan pembelajaran dengan kategori baik; 3) Keefektifan perangkat pembelajaran: (a) Ketuntasan klasikal mencapai 100\%; (b) Hasil penurunan miskonsepsi yang dialami oleh peserta didik kelas XMIA-1 64,33\%, kelas XMIA-2 42,33\%, kelas XMIA-3 32,50\%; Penurunan miskonsepsi oleh rata-rata mencapai 63,53\%; Berdasarkan hasil penelitian, dapat disimpulkan bahwa perangkat pembelajaran fisika strategi konflik kognitif berbasis eksperimen yang dikembangkan memenuhi kriteria validitas, kepraktisan, dan keefektifan sehingga layak digunakan untuk mereduksi miskonsepsi peserta didik SMA pada materi fluida statis.

Kata Kunci: Perangkat Pembelajaran, Strategi Konflik Kognitif, Miskonsepsi, Certainty of Response Index (CRI).

\section{PENDAHULUAN}

Kesalahan dalam memahami konsep sering ditemui dalam pembelajaran fisika. Konsep awal peserta didik seringkali tidak sesuai dengan konsep ilmiah yang telah disepakati para ahli, keadaan dimana peserta didik mengalami kesalahan dalam memahami konsep ini disebut dengan miskonsepsi. Miskonsepsi adalah salah satu penyebab kesulitan dalam pembelajaran fisika. Miskonsepsi adalah suatu ide atau pandangan yang salah tentang suatu konsep yang dimiliki seseorang dimana konsep tersebut berbeda dengan konsep yang telah disepakati dan dianggap benar oleh para ahli. Selain itu, miskonsepsi terjadi karena kesalahan yang dilakukan seseorang dalam membangun konsepsi berdasarkan informasi lingkungan fisik disekitarnya atau teori yang telah diterima. Miskonsepsi umumnya menyangkut kesalahan pemahaman hubungan antar konsep. Miskonsepsi disebabkan oleh beberapa hal diantaranya dari peserta didik sendiri, guru yang mengajar, konteks pembelajaran, cara mengajar, dan buku teks (Suparno, 2013).

Miskonsepsi terdapat dalam semua bidang sains termasuk fisika. Miskonsepsi yang terbesar dalam fisika terjadi pada bidang mekanika, salah satunya adalah mengenai fluida statis (Suparno, 2013). Beberapa peserta didik berpendapat bahwa jika benda tenggelam dalam air hal itu disebabkan karena berat benda lebih dari berat air, namun mengapa kapal pesiar yang sangat besar dan berat tidak tenggelam dalam air. Beberapa peserta didik juga beranggapan bahwa tekanan fluida pada zat cair hanya mengarah ke bawah (Suparno, 2013). Hal ini diperkuat oleh hasil penelitian (Kamilah \& Suwarna, 2019; Banawi et al., 2022) bahwa masih terdapat banyak peserta didik yang mengalami miskonsepsi pada konsep fluida statis. Berdasarkan hasil pre-test yang diberikan pada siswa, ditemukan sebanyak $53,7 \%$ siswa yang mengalami miskonsepsi. Adapun miskonsepsi yang terjadi pada siswa di antaranya adalah: 1) besarnya tekanan zat cair ditentukan oleh luas penampang 
bejana, volume serta massa dari zat, 2) tekanan dipengaruhi oleh luas penampang bejana, 3) semakin berat benda, maka benda akan tenggelam, 4) massa jenis cairan sebanding dengan berat benda jika massa jenisnya besar, maka bendanya juga berat, 5) volume zat cair yang dipindahkan berbanding terbalik dengan gaya apung, 6) keterapungan benda dipengaruhi oleh massa suatu benda.

Peneliti telah melakukan observasi menggunakan tes diagnostik dan wawancara kepada guru fisika untuk mengidentifikasi miskonsepsi fluida statis dengan sasaran peserta didik yang telah mengalami pembelajaran konsep fluida statis, yaitu peserta didik kelas X MIA SMA Negeri 08 Maluku Tengah diperoleh simpulan bahwa: Pertama, Berdasarkan hasil ujicoba pada setiap indikator diperoleh hasil observasi tes diagnostik yaitu (1) rata-rata persentase peserta didik yang mengalami tahu konsep (TK) sebesar 37,33\%, tidak tahu konsep (TTK) sebesar 12\%, dan miskonsepsi (MK) sebesar 50,67\%; (2) beberapa konsep fluida statis memberikan dampak yang kuat terhadap miskonsepsi peserta didik diantaranya: (a) sebanyak $57,14 \%$ peserta didik pada konsep massa jenis, (b) 50\% peserta didik konsep tekanan hidrostatis, (c) 65\% peserta didik pada konsep prinsip Pascal, dan (d) konsep prinsip Archimedes, dialami oleh 31,67\% peserta didik. Kedua, hasil wawancara guru fisika yaitu (1) guru kelas X MIA SMA Negeri 08 Seram Utara masih kurang menggunakan inovasi dalam pembelajaran ke peserta didik; (2) pembelajaran di kelas masih didominasi oleh guru sebagai sumber informasi.

Strategi pembelajaran yang sesuai diperlukan untuk menangani miskonsepsi yang dimiliki peserta didik. Salah satu strategi pembelajaran yang digunakan untuk mengatasi miskonsepsi peserta didik adalah strategi konflik kognitif. Seperti yang dikemukakan oleh Berg (1991, p. 48) bahwa miskonsepsi peserta didik tidak dapat dihilangkan hanya dengan menggunakan metode ceramah, tanpa melalui suatu proses belajar yang melibatkan peserta didik secara langsung dan aktif dalam mencari solusi terhadap konflik kognitifnya. Metode pengelolaan konflik kognitif yang dialami peserta didik merupakan hal penting dalam proses pembelajaran, karena konflik kognitif dapat mengarahkan peserta didik pada hasil yang destruktif maupun konstruktif. Cara terbaik untuk memperbaiki miskonsepsi adalah melakukan kegiatan pembelajaran yang dapat memunculkan konflik pada kognitif peserta didik, misalnya dengan melakukan demonstrasi menunjukan suatu peristiwa yang bertentangan dengan konsep awal orang yang mengalami miskonsepsi, sehingga perbaikan konsep dapat dilakukan menggunakan miskonsepsi itu sendiri yaitu dengan cara menciptakan konflik kognitif (Masyuni \& Asyhari, 2019; Palisoa, 2020). Berdasarkan uraian tersebut tujuan penelitian ini adalah mengembangkan perangkat pembelajaran pembelajaran berbasis strategi konflik kognitif dengan metode eksperimen untuk mereduksi miskonsepsi fisika SMA

\section{METODE}

Penelitian ini adalah jenis penelitian pengembangan. Pengembangan perangkat pembelajaran diadaptasi dari model four-D (4-D) terdiri atas empat tahap yaitu tahap pendefinisian (define), tahap perancangan (design), tahap pengembangan (develop), dan tahap penyebaran (disseminate) (Nasrah et al., 2017). Dalam penelitian ini Modifikasi dari 4D model menjadi 3D model Thiagarajan, Semmel, dan Semmel (1974) yang terdiri dari 4 tahapan yaitu Define, Design, dan Develop, tanpa Disseminate (Ose, 2017). Perangkat pembelajaran yang dikembangkan adalah RPP, LKPD (Lembar Kerja Peserta Didik), BAS (Buku Ajar Siswa) dan Instrumen Evaluasi. Pengembangan perangkat pembelajaran fisika dikembangkan berdasarkan strategi konflik kognitif berbasis eksperimen. Uji coba perangkat dilakukan dengan menggunakan rancangan pre-experimental one-group pretest-posttest design, karena menggunakan satu kelompok tanpa ada kelompok pembanding. Rancangan penelitian yang dilakukan pada ujicoba I dan ujicoba II menggunakan one-group pretest-posttest design dengan menggunakan satu kelompok subjek dengan pola sebagai berikut: (Sugiyono, 2014. p. 72).

\section{$\mathrm{O}_{1} \mathrm{X} \mathrm{O}_{2}$}

\section{Keterangan:}

$\mathrm{O}_{1}$ adalah: pretest untuk mengetahui miskonsepsi peserta didik terhadap materi pelajaran sebelum pembelajaran.

$\mathrm{O}_{2}$ adalah: posttest untuk mengetahui miskonsepsi peserta didik terhadap materi pelajaran setelah pembelajaran. 
$\mathrm{X}$ adalah: perlakuan pembelajaran dengan menggunakan perangkat pembelajaran strategi konflik kognitif berbasis eksperimen (Hasanah \& Wasis, 2021).

Variabel penelitian yang diamati dalam penelitian ini adalah meliputi: 1) Validitas Perangkat Pembelajaran; 2) Kepraktisan Perangkat Pembelajaran; dan 3) Keefektifan perangkat pembelajaran.

\section{Analisis Validitas Perangkat Pembelajaran}

Analisis validitas perangkat pembelajaran yang dikembangkan ditentukan dengan cara menghitung ratarata skor penilaian oleh tiga orang validator. Skor penilaian menggunakan skala Likert dengan nilai skor 1-4. Skor 4 diberikan apabila aspek yang dinilai validator pada lembar validasi baik. Skor 3 diberikan apabila aspek yang dinilai validator pada lembar validasi cukup baik (Ose, 2017). Skor 2 diberikan apabila aspek yang dinilai pada lembar validasi kurang baik dan skor 1 diberikan apabila tidak melaksanakan aspek yang dituliskan dalam lembar validasi. Skor validasi yang diperoleh diberikan kriteria pada Tabel 1 berikut:

Tabel I. Kriteria Kategori Lembar Penilaian Validasi

\begin{tabular}{ccl}
\hline Interval Skor & Kategori & \multicolumn{1}{c}{ Keterangan } \\
\hline $1,00 \leq \mathrm{SVP} \leq 1,59$ & Tidak valid & Tidak dapat digunakan dan masih memerlukan konsultasi \\
$1,60 \leq \mathrm{SVP} \leq 2,59$ & Kurang valid & Dapat digunakan dengan banyak revisi \\
$2,60 \leq \mathrm{SVP} \leq 3,59$ & Valid & Dapat digunakan dengan sedikit revisi \\
$3,60 \leq \mathrm{SVP} \leq 4,00$ & Sangat Valid & Dapat digunakan tanpa revisi \\
\hline
\end{tabular}

(Ratumanan dan Laurens, 2011)

\section{Analisis Kepraktisan Perangkat Pembelajaran}

Kepraktisan perangkat pembelajaran didapatkan dari hasil keterlaksanaan proses pembelajaran melalui aktivitas guru dan peserta didik yang tertuang dalam RPP yang diperoleh dari hasil pengamatan 2 orang pengamat dengan mengisi lembar penilaian keterlaksanaan. Kemudian rata-rata penilaian dari dua pengamat tersebut untuk setiap aspek yang diamati ditentukan sesuai kategori sebagai berikut:

$\begin{array}{ll}\text { Tidak baik } & =1.00-1.99 \\ \text { Kurang baik } & =2.00-2.99 \\ \text { Cukup baik } & =3.00-3.49 \\ \text { Baik } & =3.50-4.00\end{array}$

\section{Analisis Keefektifan Perangkat Pembelajaran}

a) Analisis Hasil Belajar

Peserta didik secara individual dikatakan tuntas jika rata-rata ketercapaian pada indikator yang mewakili tujuan pembelajaran telah memenuhi Kriteria Ketuntasan Minimum (KKM) mata pelajaran fisika di SMA N 08 Maluku tengah yaitu nilai $\geq 75$. Jika nilai minimal peserta didik telah mencapai 75 perlu diperhatikan nilai $\mathrm{N}$-Gain masing-masing peserta didik sebagai indikator yang menunjukan peningkatan hasil belajar peserta didik sebelum dan setelah pemberian perlakuan (Wahab et al., 2021).

$$
N-\text { Gain }=\frac{S_{\text {post }}-S_{\text {pre }}}{S_{\text {max }}-S_{\text {pre }}}
$$

Hasil perhitungan N-Gain selanjutnya dikonversikan menggunakan kriteria berikut:

Tabel 2. Kriteria Normalized Gain

\begin{tabular}{cc}
\hline Skor $N$-Gain & Kriteria Normalized Gain \\
\hline $0.70<N$-Gain & Tinggi \\
\hline $0.30 \leq N$-Gain $\leq 0.70$ & Sedang \\
\hline N-Gain $<0.30$ & Rendah \\
\hline & Hake (1999)
\end{tabular}


b) Analisis Penurunan Miskonsepsi

Analisis penurunan miskonesepsi Kelompok dilakukan dengan mengunakan rata-rata nilai CRI tiap peserta didik. Rata-rata nilai CRI untuk jawaban benar disebut dengan CRIB dan rata-rata nilai CRI untuk jawaban salah disebut dengan CRIS. Hasil bagi antara peserta didik yang menjawab benar dengan jumlah total peserta didik disebut dengan fraksi benar (FB).

$$
\begin{aligned}
& C R I \mathrm{~B}=\frac{\text { total jumlah CRI dari jawaban benar }}{\text { jumlah siswa yang menjawab benar }} \\
& \text { CRIS }=\frac{\text { total jumlah } \text { CRI dari jawaban salah }}{\text { jumlah siswa yang menjawab salah }} \\
& \mathrm{FB}=\frac{\text { jumlah siswa yang menjawab benar }}{\text { total jumlah siswa }}
\end{aligned}
$$

Jika rata-rata nilai CRIS yang mendekati atau sama dengan 2,5 dan fraksi benarnya rendah (FB < 0,5), maka CRIS tersebut dapat digolongkan CRI tinggi. Jika pada CRIS tersebut fraksi benarnya tinggi (FB > 0,5), maka CRIS tersebut digolongkan CRI rendah karena proporsi peserta didik yang menjawab benar lebih besar (Hasan, Bagayoko, \& Kelly, 1999).

c) Analisis Respons Siswa

Analisis respons siswa yang diberikan dianalisis dengan menggunakan analisis deskriptif kuantitatif berupa persentase. Persentase tiap respons dihitung dengan menggunakan rumus:

$$
\text { Respons }=\left(\frac{\text { Jumlah aspek yang muncul }}{\text { Jumlah siswa }}\right) \times 100 \%
$$

Persentase respons siswa diadaptasi dari Riduwan (2010) dengan kriteria sebagai berikut:

$$
\begin{array}{ll}
0 \%-20 \% & =\text { Tidak Baik } \\
21 \%-40 \% & =\text { Kurang Baik } \\
41 \%-60 \% & =\text { Cukup Baik } \\
61 \%-80 \% & =\text { Baik } \\
81 \%-100 \% & =\text { Sangat Baik }
\end{array}
$$

\section{HASIL DAN PEMBAHASAN}

\section{Analisis Validitas Perangkat Pembelajaran}

Hasil Validasi Pengembangan perangkat pembelajaran meliputi RPP, BAS, LKPD, dan soal tes miskonsepsi ditunjukan pada gambar 1 .

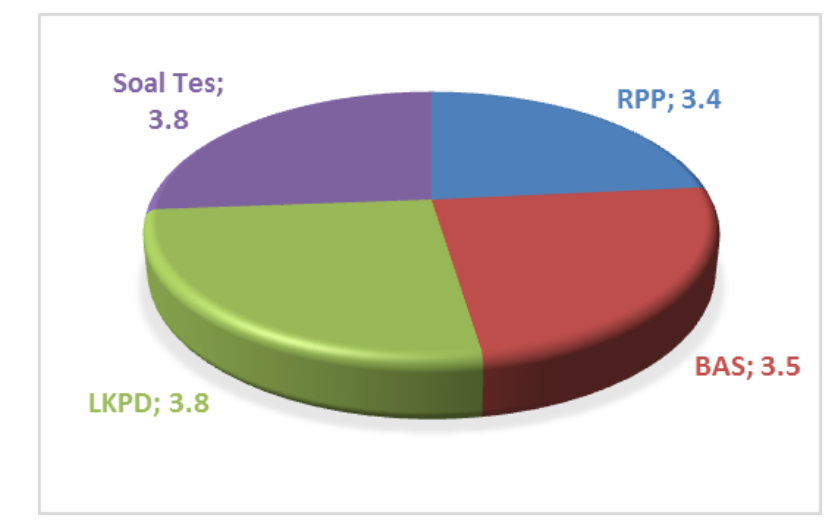

Gambar 1. Hasil Validasi perangkat pembelajaran fisika

(Sumber: Data hasil penelitian)

Hasil Analisis validasi perangkat pembelajaran fisika dengan strategi konflik kognitif berbasis eksperimen yang dikembangkan dikategotikan valid apabila memenuhi validitas minimal skor rata-rata 2,6 (Ratumanan dan Lauren, 2011). Perangkat pembelajaran RPP, BAS, LKPD dan Soal Tes yang dibuat 
mendapatkan nilai validasi rata-rata RPP 3,4, rata-rata BAS 3,5, rata-rata LKPD 3,8 dan soal tes 3,8. Kategori valid diperoleh karena telah melewati berbagai tahapan diantaranya yaitu tahapan, analisis kebutuhan, tahapan analisis peserta didik, tahapan analisis konsep, tahapan analisis tugas, tahapan diskusi dengan guru fisika SMA, dan masukan oleh ketiga validator. Rata-rata validator menyampaikan bahwa BAS yang dikembangkan harus memuat contoh-contoh yang kontekstual atau sesuai dengan pengalaman belajar peserta didik, sedangkan untuk LKPD yang dikembangkan harus memancing peserta didik dengan pertanyaan terbuka sehingga memberi ruang keluasan berpikir bagi peserta didik serta gambar-gambar yang ditampilakan harus disertakan dengan keterangan. Hasil validasi perangkat tersebut kemudian dapat digunakan dalam pembelajaran fisika untuk menurunkan miskonsepsi peserta didik SMA pada materi fluida statis (Ose, 2017).

\section{Kepraktisan Perangkat Pembelajaran}

Kepraktisan perangkat pembelajaran yang dikembangkan diperoleh dari hasil keterbacaan perangkat pembelajaran dan kendala yang dihadapi. Hasil keterlaksanaan RPP ditampilkan pada grafik di Gambar 2, Gambar 3, dan Gambar 4 berikut.

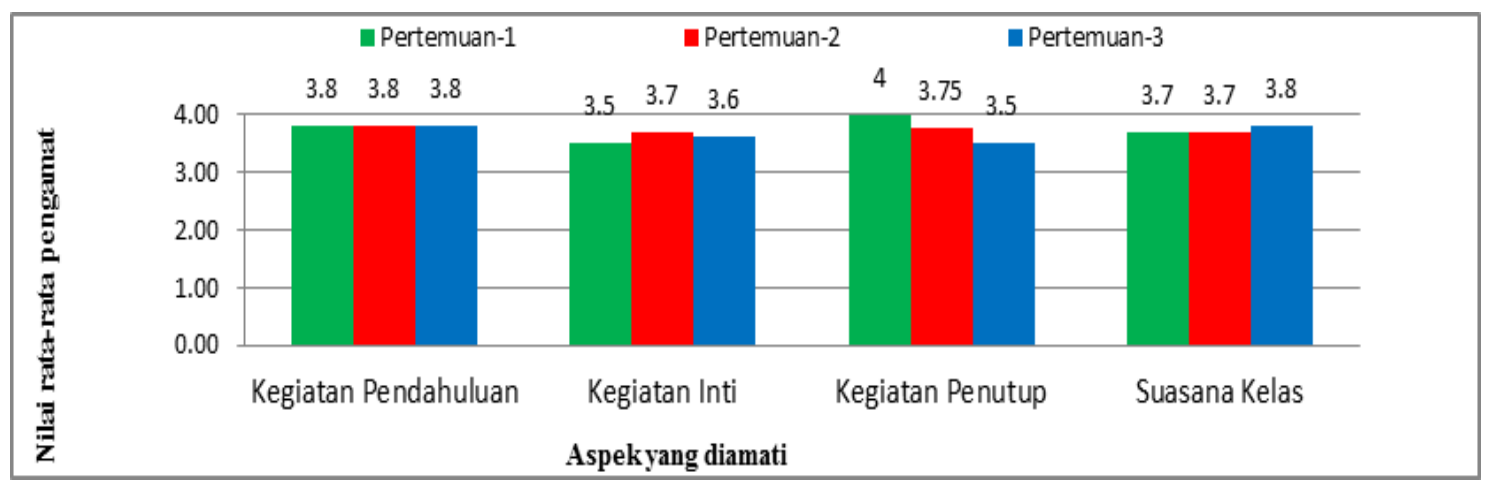

Gambar 2. Hasil keterlaksanaan perangkat pembelajaran fisika kelas X MIA-1

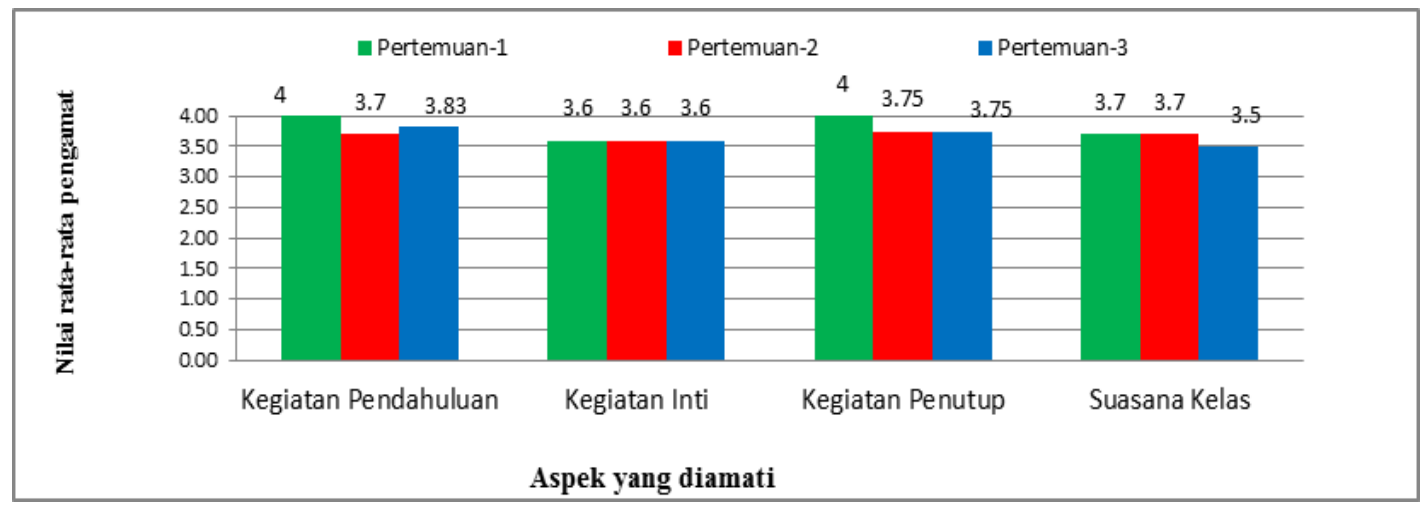

Gambar 3. Hasil keterlaksanaan perangkat pembelajaran fisika kelas X MIA-2

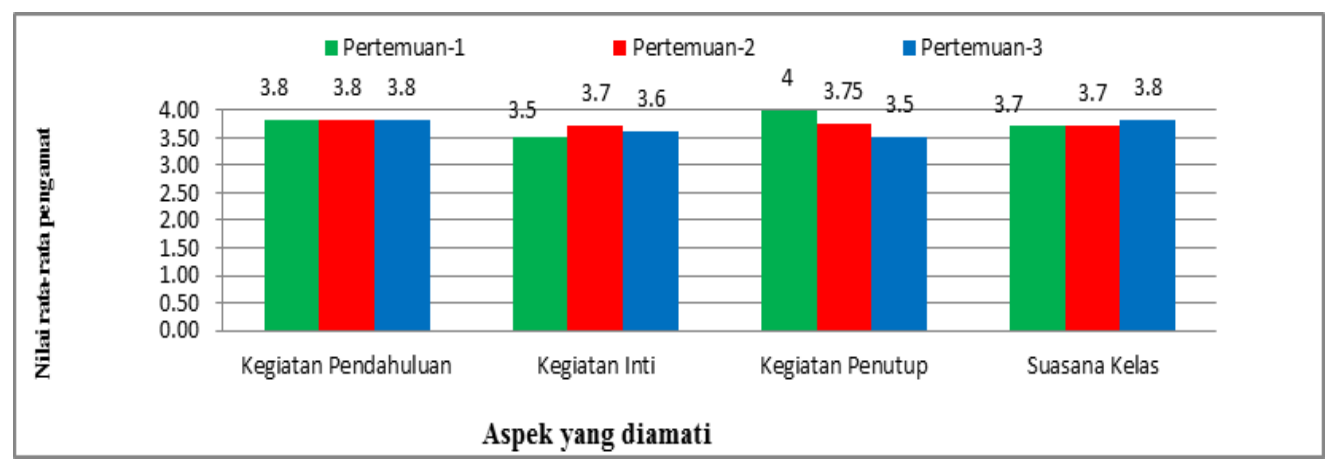

Gambar 4. Hasil keterlaksanaan perangkat pembelajaran fisika kelas X MIA-3

Keterlaksanaan perangkat pembelajaran minimal harus memperoleh skor 3,5 agar dikatakan berkategori baik. Secara keseluruhan hasil keterlaksanaan RPP yaitu: 1) kelas X MIA-1 pada pertemuan pertama skor ratarata yang diperoleh 3,55 dengan kategori baik, pada pertemuan kedua skor rata-rata yang diperoleh 3,75 
dengan kategori baik, dan pertemuan ketiga rata-rata skir yang diperoleh 3,9 dengan kategori sangat baik. 2) kelas X MIA-2 pada pertemuan pertama skor rata-rata yang diperoleh 3,83 dengan kategori baik, pada pertemuan kedua skor rata-rata 3,7 dengan kategori baik, dan Pertemuan ketiga skor yang diperoleh rata-rata 3,9 dengan kategori baik. 3) kelas X MIA-3 pada pertemuan pertama skor rata-rata diperoleh 3,75 dengan kategori baik, pada pertemuan kedua skor rata-rata yang diperoleh 3,5 dengan kategori cukup baik, dan pertemuan ketiga mendapat skor rata-rata 3,75 dengan kategori baik (Suharsimi, 2013, p. 125). Keterlaksanaan RPP pada kelas X MIA-1, kelas X MIA-2, dan kelas X MIA-3 umumnya mengalami peningkatan efektivitas pada setiap pertemuan dari pertemuan pertama meningkat ke pertemuan kedua dan meningkat lagi ke pertemuan ketiga. Terjadinya peningkatan keterlaksanaan RPP karena peneliti melakukan evaluasi bersamasama dengan pengamat disetiap selesai pembelajaran. Seperti pelaksanaaan kegiatan pembelajaran di kelas kadang tidak sesuai dengan yang di RPP serta kurangnya pengendalian atau pengontrolan suasana kelas oleh guru karena biasnya pertanyaan dan respon dari peserta didik. Sehingga dari hasil rekomendasi dan saran dari berbagai pihak tersebut dijadikan acuan bagi peneliti untuk melakukan perbaikan pada pertemuan selanjutnya. Sehingga kesimpulan dari keterlaksanaan keseluruhan RPP pada kelas X MIA-1, kelas X MIA-2, dan kelas X MIA-3 yaitu baik, yang berarti guru mampu mengelola pembelajaran sesuai dengan tahapan-tahapan strategi konflik kognitif berbasis eksperimen dengan baik. Guru mampu mengorganisir peserta didik ke dalam pembelajaran aktif dan menyenangkan. Peserta didik mendapat kesempatan untuk mengeksplorasi pengetahuan awal supaya menemukan sendiri jawaban dari permasalahan yang dihadapi (Ose, 2017)

\section{Keefektifan perangkat pembelajaran dapat diperoleh dari penurunan miskonsepsi, hasil belajar}

a) Penurunan Miskonsepsi

Tabel 1. Penurunan miskonsepsi berdasarkan konsep

\begin{tabular}{lccc}
\hline \multirow{2}{*}{ Konsep } & \multicolumn{3}{c}{ Persentase Penurunan MK } \\
\cline { 2 - 4 } & Kls X MIA-1 & Kls X MIA-2 & Kls X MIA-3 \\
\hline 1. Tekanan Hidrostatis & 62 & 76,19 & 68,57 \\
2. Prinsip Pascal & 60 & 54,76 & 57,61 \\
3. Prinsip Archimedes & 60 & 46,11 & 66,11 \\
\hline
\end{tabular}

Tabel 2. Penurunan miskonsepsi masing-masing peserta didik

\begin{tabular}{cccc}
\hline \multirow{2}{*}{ Kelas } & \multicolumn{3}{c}{ Persentase Miskonsepsi } \\
\cline { 2 - 4 } & Pretest & Posttest & Penurunan \\
\hline X MIA-2 & 72,00 & 7,67 & 64,33 \\
X MIA-3 & 43,33 & 1,00 & 42,33 \\
X MIA-4 & 68,33 & 4,50 & 63,83 \\
\hline
\end{tabular}

Tabel 3. Penurunan miskonsepsi berdasarkan nilai FB

\begin{tabular}{ccccccc}
\hline \multirow{2}{*}{ Kelas } & \multicolumn{3}{c}{ Pretest } & \multicolumn{3}{c}{ Posttest } \\
\cline { 2 - 7 } & FB & K & P & FB & K & P \\
\hline X MIA-2 & 0,20 & T & BS & 0,97 & R & BB \\
X MIA-3 & 0,18 & T & BS & 0,97 & R & BB \\
X MIA-4 & 0,17 & T & BS & 0,96 & R & BB \\
\hline
\end{tabular}

Keterangan:

$\begin{array}{lll}\mathrm{FB}=\text { Fraksi Benar } ; & \mathrm{K}=\text { Kategori } ; & \mathrm{T}=\text { Tinggi; } \\ \mathrm{BS}=\text { Banyak Salah; } & \mathrm{P}=\text { Proporsi } ; & \mathrm{R}=\text { Rendah; }\end{array}$

$\mathrm{BB}=$ Banyak Benar.

Penurunan miskonsepsi pada penelitian ini dilihat dari beberapa bagian meliputi konsep materi, masing-masing peserta didik dan nilai FB dari analisis CRI diperoleh beberapa fakta: 1) fakta dari hasil pretest yaitu masih rendahnya pemahaman konsep peserta didik yang disebabkan oleh adanya miskonsepsi dan kesalahan konsepsi peserta didik, hal ini terjadi karena sebelum peserta didik masuk mengikuti pembelajaran fisika, peserta didik sudah sering mengalami pengalaman dengan peristiwa-peristiwa fisika dalam kehidupan 
sehari-hari yang berakibat terbangun sebuah konsepsi dalam diri peserta didik yang bisa saja merupakan konsep benar atau konsep yang belum tentu sama dengan konsepsi fisikawan, konsep semacam itu disebut prakonsepsi (Hasan et al., 1999; Berg 1991, p. 40). 2) fakta hasil posttest dengan kegiatan belajar mengajar menggunakan strategi konflik kognitif berbasis eksperimen membuat peserta didik terlibat langsung secara aktif dalam proses menemukan jawaban sendiri dari permasalahan yang dialami. Siswa menghadapi sendiri dan menyelesaikan masalah yang dihadapi yang dampaknya pada peserta didik semakin menguasai konsep dengan benar (Nurhidayah et al., 2020; Prodjosantoso et al., 2019). 3) peserta didik mengalami peningkatan penguasaan konsep atau tahu konsep yang mengakibatkan terjadinya penurunan miskonsepsi peserta didik serta ketuntasan belajar peserta didik telah mencapai KKM baik secara individual maupun klasikal. Peserta didik mengalami penurunan miskonsepsi berdasarkan hasil analisis dengan CRI menggunakan strategi konflik kognitif berbasis eksperimen. Hal ini didukung juga oleh penelitian yang dilakukan oleh (Wartono et al., 2018; Hidayatullah et al., 2020; Hasanah \& Wasis, 2021) yang menyimpulkan bahwa strategi konflik kognitif berbasis eksperimen mampu mereduksi miskonsepsi peserta didik.

b) Hasil Belajar

Hasil belajar peserta didik diperoleh dari ketuntasan indikator pada setiap tujuan pembelajaran dan nilai KKM yang diperoleh peserta didik. Nilai KKM masing-masing peserta didik kelas X MIA-1, kelas X MIA-2, dan kelas X MIA-3 SMA Negeri 08 Maluku Tengah dinyatakan mencapai nilai KKM untuk mata pelajaran fisika bila mendapat skor $\geq 75$ (Kemendikbud, 2013) dapat dilihat pada Tabel 4.

Tabel 4. Ketuntasan hasil belajar

\begin{tabular}{|c|c|c|c|c|c|c|c|}
\hline \multirow{2}{*}{ Kelas } & \multicolumn{2}{|c|}{ Pre-Test } & \multirow{2}{*}{ Ket } & \multicolumn{2}{|c|}{ Post-Test } & \multirow{2}{*}{$\begin{array}{c}\text { Rata-rata } \\
\text { N-Gain }\end{array}$} & \multirow{2}{*}{ Ket } \\
\hline & Individu & Klasikal & & Individu & Klasikal & & \\
\hline X MIA-1 & 56,67 & $61,53 \%$ & Tidak Tuntas & 87,67 & $100 \%$ & 0,82 & Tuntas \\
\hline X MIA-2 & 60,45 & $76,67 \%$ & Tidak Tuntas & 98,33 & $100 \%$ & 0,99 & Tuntas \\
\hline X MIA-3 & 57,83 & $78,57 \%$ & Tidak Tuntas & 95,67 & $100 \%$ & 0,95 & Tuntas \\
\hline
\end{tabular}

Data di atas menunjukkan bahwa nilai pretest yang diperoleh peserta didik pada masing-masing kelas menunjukkan kemampuan awal peserta didik secara individu memeroleh ketuntasan individual yang rendah dengan predikat tidak tuntas. Kemudian diberikan perlakukan pembelajaran remedial dengan strategi konflik kognitif berbasis eksperimen sebanyak tiga kali pertemuan kemudian diberikan posttest. Hasil posttest yang diperoleh peserta didik pada masing-masing kelas menunjukkan secara individu semua peserta didik mencapai KKM dan secara klasikal memeroleh ketuntasan hasil belajar 100\%, dan berdasarkan nilai N-Gain rata-rata berkategori tinggi, hanya saja ada beberapa peserta didik yang memeroleh nilai N-Gain berkategori sedang. Peserta didik-peserta didik yang memeroleh N-Gain kategori sedang, disebabkan karena peserta didik tersebut memiliki aktivitas pembelajaran yang rendah bila di bandingkan dengan peserta didik-peserta didik yang memperoleh ketuntasan belajar dengan nilai N-Gain kategori tinggi, di mana memiliki aktivitas pembelajaran yang tinggi. Hasil Penelitian pengembangan perangkat ini diperkuat oleh penelitian (Palisoa, 2020; Hidayatullah et al., 2020; Hewson \& hewson, 1984 ) yang menyimpulkan bahwa strategi konflik kognitif mampu mereduksi miskonsepsi peserta didik dan meningkatkan hasil belajar.

c) Respon peserta didik

Hasil penyebaran angket respon peserta didik terhadap proses pembelajaran yang telah dilaksanakan, diperoleh data bahwa rata-rata siswa merespon positif terhadap kriteria-kriteria yang diajukan. Sebanyak 94\% dari seluruh responden merasa tertarik terhadap kegiatan pembelajaran yang dilaksanakan dan berharap supaya pada kegiatan pembelajaran berikutnya dilakukan kegiatan yang sama.

\section{SIMPULAN}

Berdasarkan data temuan hasil penelitian dan pembahasan dapat disimpulkan bahwa perangkat pembelajaran fisika strategi konflik kognitif berbasis eksperimen yang dikembangkan sudah memenuhi kriteria validitas, kepraktisan, dan keefektifan sehingga layak digunakan untuk mereduksi miskonsepsi siswa SMA pada materi fluida statis. Hasil Validasi Pengembangan perangkat pembelajaran mendapatkan nilai validasi rata-rata RPP 3,4, rata-rata BAS 3,5, rata-rata LKPD 3,8 dan soal tes 3,8. Keterlaksanaan RPP pada kelas X MIA-1, kelas 
X MIA-2, dan kelas X MIA-3 umumnya mengalami peningkatan efektivitas pada setiap pertemuan. Penurunan miskonsepsi X MIA-1 terjadi sebesar 64,33\%, X MIA-2 sebesar 42,33\% dan X MIA-3 sebesar 63,83\%.

\section{Daftar Pustaka}

Banawi, A., Sopandi, W., Kadarohman, A., \& Solehuddin, M. (2022). Five-Tier Multiple-Choice Diagnostic Test Development: Empirical Evidences to Improve Students' Science Literacy. Proceedings of the International Conference on Madrasah Reform 2021 (ICMR 2021), 633(Icmr 2021), 131-138. https://doi.org/10.2991/assehr.k.220104.020

Hasan, S., Bagayoko, D., \& Kelley, E. L. (1999). Misconceptions and the certainty of response index (CRI). Physics Education. https://doi.org/10.1088/0031-9120/34/5/304

Hammer, D. (1996). "More than misconceptions: multiple perspectives on student knowledge and reasoning and appropriate role for education research". Am. J. Phys, pp.1316-1325.

Hasanah, D. I., \& Wasis, W. (2021). Cognitive Conflict Strategy Assisted by PhET Simulation to Remediate Student's Misconceptions on Wave Material. Asatiza: Jurnal Pendidikan. https://doi.org/10.46963/asatiza.v2i1.247

Hewson, P.W., Hewson, M.G.A. The role of conceptual conflict in conceptual change and the design of science instruction. Instr Sci 13, 1-13 (1984). https://doi.org/10.1007/BF00051837

Hidayatullah, Z., Jumadi, Nadhiroh, N., Kartika, E., Ainun, A., \& Erlangga, sony yunior. (2020). Identification of Misconception and Cognitive Conflict of Physics: A Case Related to Conceptual Change. 12(1), 64-71.

Kamilah, D. S., \& Suwarna, I. P. (2019). Pengembangan Three-Tier Test Digital untuk mengidentifikasi miskonsepsi pada Konsep Fluida Statis. Edusains, 8(2), 212-220. https://doi.org/10.15408/es.v8i2.5192

Masyuni, S., \& Asyhari, A. (2019). Implementasi pendekatan konflik kognitif berbasis metode eksperimen terhadap penguasaan konsep dan kemampuan berpikir kritis. Indonesian Journal of Science and Mathematics Education, 2(2), 184-193. https://doi.org/10.24042/ijsme.v2i2.4324

Nasrah, Jasruddin, \& Tawil, M. (2017). Pengembangan perangkat pembelajaran Fisika berbasis pendekatan Contexstual Teaching and Learning (CTL) untuk Memotivasi dan Meningkatkan Hasil Belajar Fisika Peserta Didik Kelas VIII SMP Negeri 1 Balocci Pangkep. Jurnal Pendidikan Fisika, 5(2), 235-248. https://doi.org/10.26618/jpf.v5i2.709

Nurhidayah, Suharto, B., \& Leny. (2020). The Application of a Guided Inquiry Model in an Effort to Reduce Students ' Misconceptions in the Redox Reaction Material. JCAE: Journal of Chemistry And Education, 4(2), $67-72$.

Ose, L. (2017). Pengembangan Perangkat Pembelajaran dengan Pendekatan PMR untuk Meningkatkan Hasil Belajar Siswa. Kreano, Jurnal Matematika Kreatif-Inovatif, 8(1), 101-108. https://doi.org/10.15294/kreano.v8i1.6981

Palisoa, N. (2020). Strategi Strategi Konflik Kognitif Dapat Mereduksi Beban Miskonsepsi Mahasiswa Calon Guru Kimia Pada Konsep Ikatan Kimia. Molluca Journal of Chemistry Education (MJoCE). https://doi.org/10.30598/mjocevol10iss2pp109-114

Paul Suparno. (2013). Miskonsepsi dan perubahan konsep dalam pendidikan fisika / Paul Suparno. Jakarta: Grasindo.

Prodjosantoso, A. K., Hertina, A. M., \& Irwanto. (2019). The misconception diagnosis on ionic and covalent bonds concepts with three tier diagnostic test. International Journal of Instruction, 12(1), 1477-1488. https://doi.org/10.29333/iji.2019.12194a

Ratumanan, T. G., \& Laurens. (2011). Evaluasi hasil belajar yang relevan dengan Kurikulum Berbasis Kompetensi. Surabaya: Unesa University Press.

Suharsimi Arikunto. (2013). Dasar-dasar evaluasi pendidikan edisi 2. Jakarta: Bumi Aksara 
Suparno, P. (2013). Miskonsepsi dan perubahan konsep dalam pendidikan fisika. Jakarta: Grasindo.

Sugiyono. (2014). Metode penelitian kombinasi. Bandung: AlfaBeta.

Thiagarajan \& Semmel. (1974). Instructional development for traning teacher of exceptional children a sourcebook. Indiana: Indiana University

Wahab, A., Junaedi, J., \& Azhar, M. (2021). Efektivitas Pembelajaran Statistika Pendidikan Menggunakan Uji Peningkatan N-Gain di PGMI. Jurnal Basicedu, 5(2), 1039-1045. https://doi.org/10.31004/basicedu.v5i2.845

Wartono, W., Batlolona, J. R., \& Putirulan, A. (2018). Cognitive Conflict Strategy and Simulation Practicum to Overcome Student Misconception on Light Topics. Journal of Education and Learning (EduLearn). https://doi.org/10.11591/edulearn.v12i4.10433 